\title{
Sex differences in cancer survival in Estonia: a population-based study
}

Kaire Innos ${ }^{1 *}$, Peeter Padrik ${ }^{2,3}$, Vahur Valvere ${ }^{4,5}$ and Tiiu Aareleid ${ }^{1}$

\begin{abstract}
Background: In Estonia, women have much longer life expectancy than men. The aim of this study was to examine sex differences in cancer survival in Estonia and to explore the role of age at diagnosis, stage at diagnosis and tumour subsite.

Methods: Using data from the population-based Estonian Cancer Registry, we examined the relative survival of adult patients diagnosed with nine common cancers in Estonia in 1995-2006 and followed up through 2011. Excess hazard ratios (EHR) of death associated with female gender adjusted for age, stage at diagnosis and tumour subsite were estimated.

Results: A total of 20828 male and 13166 female cases were analysed. The main data quality indicators were similar between men and women. Women had more cases with unknown extent of disease at diagnosis. Overall, the age-adjusted 5-year relative survival ratio was higher among women than men for all studied sites, but the difference was significant for cancers of mouth and pharynx (22\% units), lung (5\% units), skin melanoma (17\% units) and kidney ( $8 \%$ units). The increase in survival over time was larger for women than men for cancers of mouth and pharynx, colon, rectum, kidney and skin melanoma. In multivariate analysis, women had a significantly lower EHR of death within five years after diagnosis for five of the nine cancers studied (cancers of mouth and pharynx, stomach, lung, skin melanoma and kidney). Adjustment for stage and subsite explained some, but not all of the women's advantage.
\end{abstract}

Conclusions: We found a significant female survival advantage in Estonia for cancers of mouth and pharynx, stomach, lung, kidney and skin melanoma. The differences in favour of women tended to increase over time as from the 1990s to the 2000s, survival improved more among women than among men. A large part of the women's advantage is likely attributable to biological factors, but other factors, such as co-morbidities, treatment compliance or health behaviour, are also probable contributors to gender survival disparities in Estonia and merit further investigation. Our findings have implications for public health, early detection and cancer care in Estonia.

Keywords: Relative survival, Cancer registry, Population-based, Gender differences, Data quality

\section{Background}

Women have a longer life expectancy than men; in 2012, the difference between the life expectancy at birth of women and men in Europe was 5.6 years (83.1 vs. 77.5 years, respectively) [1]. In Estonia, health disparities between sexes are even larger, as the life expectancy at birth is 81 years for women, but only 73 years for men [2]. Among all causes of death, cancer ranks second after circulatory diseases [3]. Globally, cancer mortality among

\footnotetext{
* Correspondence: kaire.innos@tai.ee

'Department of Epidemiology and Biostatistics, National Institute for Health Development, Hiiu 42, 11619 Tallinn, Estonia

Full list of author information is available at the end of the article
}

men is much higher compared to women [4]. Mostly, this difference mirrors sex differences in cancer incidence [5], but many studies have also observed sex disparities in cancer survival $[6,7]$. As hypothesised elsewhere, a considerable part of gender differences in cancer survival likely arises from inequalities in tumour biology, including host defence mechanisms, while the factors such as health behaviour, awareness of symptoms, timeliness of diagnosis and co-morbidity may also be important contributors to gender disparities [8].

The aim of this study was to analyse gender differences in cancer survival in Estonia and to explore the 
role of age at diagnosis, stage at diagnosis and tumour subsite using data from the population-based Estonian Cancer Registry (ECR). Cancer is a reportable disease in Estonia by legislation. The registry covers the whole country (population 1.34 million in 2009) and has population-based cancer data since 1968 [9]. Estonian cancer data have been included in the Cancer Incidence in Five Continents since Volume VI (data from 1983).

\section{Methods}

The ECR provided individual data with no personal identifiers on all adult (15 years and older) cases of nine most common malignancies occurring in both genders, diagnosed in Estonia in 1995-2006, regardless of cancer sequence: mouth and pharynx (ICO-O-3 topography codes $\mathrm{C} 00-\mathrm{C} 14)$; stomach $(\mathrm{C} 16)$, colon $(\mathrm{C} 18)$, rectum, rectosigmoid junction, anus $(\mathrm{C} 19-\mathrm{C} 21)$, pancreas $(\mathrm{C} 25)$, lung, trachea (C33-C34), melanoma of skin (C44), kidney, renal pelvis (C64-C65), bladder, ureter, other urinary organs (C66-C68). The following quality indicators were calculated: percentage microscopically verified (\%MV), percentage death certificate only (\%DCO), percentage autopsy and percentage unknown extent of disease. Cases diagnosed at autopsy and DCO cases were excluded from survival analysis. The patients were followed up for vital status until December 31, 2011 using linkage with the Population Registry. This routine linkage is based on unique personal identification numbers [10]. In case of death or emigration, the respective date was ascertained. Relative survival was calculated as the ratio of the observed survival of cancer patients and the expected survival of the underlying general population. The latter was calculated according to the Ederer II method using national life tables for Estonian population stratified by age, gender and calendar year. The patients were grouped into five age categories: $15-44$ years, $45-54$ years, $55-64$ years, $65-74$ years, $\geq 75$ years. The two youngest age groups were collapsed for the modelling of excess mortality except for skin melanoma. Subsites according to ICD$\mathrm{O}-3$ were considered for five cancers (mouth and pharynx, stomach, colon, rectum, skin melanoma), for which subsite may be a prognostic factor based on a priori knowledge. Extent of disease was grouped into four categories based on the information reported to the cancer registry: 1) localised; 2 ) local/regional spread (regional lymph nodes or adjacent tissues); 3) distant (distant metastases or unspecified advanced process); 4) unknown extent. For age adjustment, we used the International Cancer Survival Standards (ICSS) [11]. Age-adjusted relative survival ratios (RSR) are presented for all patients and separately for patients diagnosed in 1995-2000 and 2001-2006.

The significance of the difference between proportions was tested using a chi-square test. We estimated excess hazard ratios (EHR) of death associated with female gender within five years after diagnosis in the framework of generalized linear models using a Poisson assumption for the number of observed deaths [12]. Cases with unknown extent of disease were excluded from these analyses. All models included year of follow-up and period of diagnosis. The EHRs are presented with 95\% confidence intervals $(95 \% \mathrm{CI})$. Interactions between year of follow-up and stage or subsite were checked with likelihood ratio test.

Stata 12 software was used for all analyses. The study protocol was approved by the Tallinn Medical Research Ethics Committee (decision no. 284).

\section{Results}

A total of 20828 male and 13166 female cases of nine cancers sites were analysed. The differences between men and women in the main data quality indicators were generally small (Table 1). In both male and female patients, \%MV varied across cancer sites with the lowest result for pancreas and lung. For the same sites, \%DCO exceeded 3\% in both sexes. Skin melanoma had the highest \%MV and the lowest \%DCO. Among cased diagnosed alive, the proportion of cases with unknown extent of disease was higher in women for all sites except mouth and pharynx, and exceeded 5\% for cancers of pancreas, lung, stomach and bladder (only pancreas in men). Female patients were older than male patients: median age at diagnosis as well as the respective 75th percentile was higher among women for all sites. Age distribution by cancer site is shown in Table 2 .

Subsite distribution varied between sexes for all five cancers (Table 3). Stage distribution differed significantly for cancers of mouth and pharynx, stomach, lung, kidney and skin melanoma (Table 4).

Women had a significant survival advantage for cancers of mouth and pharynx, lung, skin melanoma and kidney (Table 5). For these sites, women also experienced superior survival in all age groups, although the advantage was generally larger among younger patients and statistically significant differences were seen only in some age categories. For bladder cancer, women had worse prognosis (non-significant) only among patients younger than 55 years.

During the first period (1995-2000), the age-adjusted five-year RSR was higher among women for all sites except colon (Table 6); the women's advantage was statistically significant for mouth and pharyngeal cancer $(20 \%$ units) and lung cancer (6\% units), while it was borderline significant for skin melanoma ( $14 \%$ units). During the second period (2001-2006), the women's advantage increased to $24 \%$ units for cancer of mouth and pharynx and $19 \%$ units for skin melanoma (both statistically significant). As kidney cancer survival increased only among women, the gender difference reached a significant difference of $13 \%$ 
Table 1 Nine common cancers in Estonia, 1995-2006

\begin{tabular}{|c|c|c|c|c|c|c|c|c|c|c|c|c|}
\hline \multirow[b]{2}{*}{$\begin{array}{l}\text { Cancer } \\
\text { site }\end{array}$} & \multicolumn{6}{|l|}{ Men } & \multicolumn{6}{|c|}{ Women } \\
\hline & $\begin{array}{l}\text { No. of } \\
\text { cases }\end{array}$ & $\% \mathrm{MV}$ & $\% \mathrm{DCO}$ & \%Autopsy & $\begin{array}{l}\text { \%Unknown } \\
\text { extent* }\end{array}$ & $\begin{array}{l}\text { Age, median } \\
\text { (IQR)* }\end{array}$ & $\begin{array}{l}\text { No. of } \\
\text { cases }\end{array}$ & $\% \mathrm{MV}$ & $\% \mathrm{DCO}$ & \%Autopsy & $\begin{array}{l}\text { \%Unknown } \\
\text { extent* }\end{array}$ & $\begin{array}{l}\text { Age, median } \\
\text { (IQR)* }\end{array}$ \\
\hline $\begin{array}{l}\text { Mouth, } \\
\text { pharynx }\end{array}$ & 1410 & 94.5 & 0.8 & 0.2 & 1.6 & $61(54-68)$ & 457 & 94.8 & 0.7 & 0.2 & 1.6 & $68(57-76)$ \\
\hline Stomach & 3003 & 90.0 & 1.7 & 1.8 & 3.6 & $67(58-73)$ & 2505 & 88.5 & 2.4 & 1.3 & 5.3 & $71(61-77)$ \\
\hline Colon & 2029 & 91.4 & 1.4 & 1.3 & 2.7 & $69(62-75)$ & 2789 & 88.5 & 1.2 & 1.6 & 3.9 & 72 (64-78) \\
\hline Rectum & 1627 & 93.6 & 1.0 & 0.5 & 2.6 & $68(61-74)$ & 1622 & 90.2 & 1.5 & 0.9 & 3.7 & $71(63-78)$ \\
\hline Pancreas & 1235 & 53.7 & 3.1 & 4.5 & 6.1 & $66(58-73)$ & 1099 & 47.3 & 3.6 & 2.2 & 7.5 & $72(64-79)$ \\
\hline Lung & 7442 & 73.6 & 3.5 & 3.2 & 4.3 & $66(60-72)$ & 1771 & 66.9 & 3.4 & 3.6 & 5.8 & $70(62-76)$ \\
\hline $\begin{array}{l}\text { Skin } \\
\text { melanoma }\end{array}$ & 539 & 98.5 & 0.7 & 0.2 & 2.8 & $62(51-71)$ & 980 & 99.1 & 0.2 & 0.3 & 3.0 & $64(49-73)$ \\
\hline Kidney & 1742 & 81.2 & 1.8 & 4.7 & 2.5 & $64(56-71)$ & 1255 & 80.1 & 1.0 & 3.2 & 4.0 & $68(60-75)$ \\
\hline Bladder & 1801 & 94.0 & 1.2 & 1.0 & 4.0 & $69(63-76)$ & 688 & 90.0 & 2.8 & 1.5 & 5.5 & $74(67-80)$ \\
\hline
\end{tabular}

Abbreviations: \%MV percentage microscopically verified, \%DCO percentage death certificate only, IQR interquartile range.

*Among cases diagnosed alive and eligible for survival analysis.

units during the second period. For lung cancer, the 6\% unit significant difference persisted throughout the study period. The increase in survival over time was much larger for women than men for both colon and rectal cancers.

Women had a significantly lower EHR of death within five years of diagnosis for five of the nine cancers studied (cancers of mouth and pharynx, stomach, lung, skin melanoma and kidney) (Table 7). In age-adjusted analyses, women had almost 50\% lower EHR of dying compared to men for cancers of mouth and pharynx and skin melanoma. Adjustment for stage and subsite explained some of the women's advantage, but a significant portion of this advantage remained unexplained. For stomach cancer, women had 10\% lower EHR of death and the inclusion of stage and subsite into the model did not change the estimates. For cancers of lung and kidney, women still had around 20\% lower EHR of dying compared to men after adjustment for stage. We observed no survival differences between men and women in any of the models for cancers of colon, rectum, pancreas and bladder.

We found evidence of interaction between year of follow-up and extent of disease (stomach, rectum, pancreas, lung melanoma, kidney and bladder) or year of follow-up and age (stomach, colon, rectum, lung, bladder); however, including the interaction term in the model did not change the risk estimates for gender, and therefore, these results are not shown.

\section{Discussion}

In this study based on data from the population-based cancer registry of Estonia, we found that women had a significant survival advantage for five of the nine common solid tumours included in the study. The direction and magnitude of the effect found in our study is consistent with the findings of the analysis of EUROCARE-4 data for cancers of mouth and pharynx, stomach, lung, and skin melanoma [6]. For kidney cancer, the women's advantage observed in our study was much larger than in the European pool. Unlike the EUROCARE-4 analysis, we did not find female survival advantage for cancers of colon, rectum and pancreas. For bladder cancer, we found no gender differences in survival whilst a significant female disadvantage was seen in the EUROCARE-4 analysis.

Age is a major determinant of survival [13]. We found that for most cancers, the gender difference in survival varied across age categories; for many sites, the women's advantage was more marked in younger age groups. It has been suggested that in this context, age is a proxy for biological factors, particularly profound hormonal changes that occur in women around the age of menopause [6]. On the other hand, in younger and middle-aged men free testosterone is hypothesised to drive cancer aggressiveness [14].

The main strength of the study was the use of goodquality population-based data, collected uniformly over the study period. The quality of the ECR has remained relatively stable from 1995 to 2008 with low \%DCO and percentage primary site uncertain [15]. In this study, we found that the main quality indicators did not vary notably by sex for any cancer site. Nevertheless, female patients were generally older than male patients, with about 2 -fold higher proportion of the age group 75 years and older for some cancers (mouth and pharynx, pancreas and bladder). This was probably the main reason for the somewhat higher proportion of cases with unknown extent of disease observed among women compared with men. As an additional strength of the study, we were able to account for two major determinants of survival - cancer subsite and extent of disease. 
Table 2 Age distribution among cancer cases eligible for survival analysis, Estonia, 1995-2006

\begin{tabular}{|c|c|c|c|c|}
\hline \multirow[b]{2}{*}{ Cancer site } & \multirow[b]{2}{*}{$\begin{array}{l}\text { Age at diagnosis } \\
\text { (years) }\end{array}$} & \multicolumn{2}{|c|}{ No. of cases (\%) } & \multirow[b]{2}{*}{ p-value* } \\
\hline & & Men & Women & \\
\hline \multirow[t]{5}{*}{ Mouth, pharynx } & $<45$ & $76(5)$ & $35(8)$ & $p<0.001$ \\
\hline & $45-54$ & $317(23)$ & $60(13)$ & \\
\hline & $55-64$ & $503(36)$ & $92(20)$ & \\
\hline & $65-74$ & $379(27)$ & $128(28)$ & \\
\hline & $\geq 75$ & $120(9)$ & $136(30)$ & \\
\hline \multirow{5}{*}{ Stomach } & $<45$ & $140(5)$ & $126(5)$ & $p<0.001$ \\
\hline & $45-54$ & $377(13)$ & $248(10)$ & \\
\hline & $55-64$ & $756(26)$ & 440 (18) & \\
\hline & $65-74$ & 1067 (37) & 801 (33) & \\
\hline & $\geq 75$ & $557(19)$ & 797 (33) & \\
\hline \multirow[t]{5}{*}{ Colon } & $<45$ & $54(3)$ & $73(3)$ & $p<0.001$ \\
\hline & $45-54$ & $159(8)$ & $183(7)$ & \\
\hline & $55-64$ & $456(23)$ & 498 (18) & \\
\hline & $65-74$ & $809(41)$ & $970(36)$ & \\
\hline & $\geq 75$ & $496(25)$ & $988(36)$ & \\
\hline \multirow[t]{5}{*}{ Rectum } & $<45$ & $44(3)$ & $56(4)$ & $p<0.001$ \\
\hline & $45-54$ & $134(8)$ & $131(8)$ & \\
\hline & $55-64$ & $428(27)$ & 307 (19) & \\
\hline & $65-74$ & $641(40)$ & $531(34)$ & \\
\hline & $\geq 75$ & $356(22)$ & $227(35)$ & \\
\hline \multirow[t]{5}{*}{ Pancreas } & $<45$ & $56(5)$ & $20(2)$ & $p<0.001$ \\
\hline & $45-54$ & $18(13)$ & $76(7)$ & \\
\hline & $55-64$ & $318(28)$ & $184(18)$ & \\
\hline & $65-74$ & $414(36)$ & $350(34)$ & \\
\hline & $\geq 75$ & $206(18)$ & 405 (39) & \\
\hline \multirow[t]{5}{*}{ Lung } & $<45$ & $132(2)$ & $43(3)$ & $p<0.001$ \\
\hline & $45-54$ & $785(11)$ & $159(10)$ & \\
\hline & $55-64$ & $2131(31)$ & $334(20)$ & \\
\hline & $65-74$ & $2859(41)$ & $610(37)$ & \\
\hline & $\geq 75$ & $1041(15)$ & $501(30)$ & \\
\hline \multirow[t]{5}{*}{ Skin melanoma } & $<45$ & $98(18)$ & $188(19)$ & $p=0.076$ \\
\hline & $45-54$ & $75(14)$ & $147(15)$ & \\
\hline & $55-64$ & $130(24)$ & $199(20)$ & \\
\hline & $65-74$ & $147(28)$ & $239(25)$ & \\
\hline & $\geq 75$ & $83(16)$ & 199 (20) & \\
\hline \multirow[t]{5}{*}{ Kidney } & $<45$ & $86(5)$ & $38(3)$ & $p<0.001$ \\
\hline & $45-54$ & $286(18)$ & $130(11)$ & \\
\hline & $55-64$ & $472(29)$ & $302(25)$ & \\
\hline & $65-74$ & $544(34)$ & 433 (36) & \\
\hline & $\geq 75$ & $229(14)$ & $290(24)$ & \\
\hline
\end{tabular}

Table 2 Age distribution among cancer cases eligible for survival analysis, Estonia, 1995-2006 (Continued)

\begin{tabular}{lllll}
\hline Bladder & $<45$ & $45(3)$ & $18(3)$ & $\mathrm{p}<0.001$ \\
& $45-54$ & $137(8)$ & $33(5)$ & \\
$55-64$ & $388(22)$ & $86(13)$ & \\
$65-74$ & $702(40)$ & $212(32)$ & \\
$\geq 75$ & $488(28)$ & $310(47)$ & \\
\hline
\end{tabular}

${ }^{*}$ Chi-squared test.

The main limitation of the study was the inability to examine the role of determinants of survival other that age, stage and subsite, such as co-morbidities, health behaviour or factors associated with tumour biology. The extent of disease at diagnosis as reported to the ECR is not as precise as TNM stage and some misclassification is possible. Misclassification of cancer subsite needs to be considered as well. However, we do not expect any of the misclassifications to be associated with gender. Relative survival compensates for general background mortality; nevertheless, for patients with tobacco-related cancers, relative survival may be underestimated because their mortality from other diseases such as cardiovascular diseases is higher than in the general population. The prevalence of smoking in men is higher than in women: according to the biannual Estonian Health Behaviour study, the prevalence of daily smokers in men age 15-64 years decreased from $45 \%$ in 1996 to $36 \%$ in 2012 (from $32 \%$ to $26 \%$ in women) [16]. Thus, some of the male disadvantage might be due to increased background mortality from smoking-related co-morbidities.

Among oropharyngeal cancers, tongue and oral cavity was the most common subsite for both genders, accounting for $2 / 5$ of the cases. The second most frequent subsite was pharynx among men (ICD-O-3 C09-C13), but salivary gland (ICD-O-3 C07-C08) among women. Based on the EUROCARE study, the summary ageadjusted 5-year RSR was significantly higher for cancers of salivary glands than pharynx (especially hypopharynx) [13]. Pharyngeal subsites were associated with considerably higher excess risk of dying compared with subsites within oral cavity in an analysis of head and neck cancers in Europe [17]. Thus, different proportions of these subsites can contribute by itself to survival advantage among women. Our results showed that the women's survival advantage was rather constant over the agespan and only slightly decreased after the age of 65 years. In women, the improvement of 5-year RSR from 1995-2000 to 2001-2006 was more rapid compared to men, and as a result, the gender difference increased. Women also had more favourable stage distribution (higher proportion of localised disease). In multivariate analysis, however, considerable women's survival advantage persisted even after adjustment for age, stage and 
Table 3 Subsite distribution among cancer cases eligible for survival analysis, Estonia, 1995-2006

\begin{tabular}{|c|c|c|c|c|c|}
\hline \multirow[b]{2}{*}{ Cancer site } & \multirow[b]{2}{*}{ Subsite } & \multirow[b]{2}{*}{ ICD-O-3 } & \multicolumn{2}{|c|}{ No of cases (\%) } & \multirow[b]{2}{*}{ p-value } \\
\hline & & & Men & Women & \\
\hline \multirow[t]{6}{*}{ Mouth, pharynx } & All & C00-14 & $1395(100)$ & $451(100)$ & $p<0.001$ \\
\hline & Lip & $\mathrm{COO}$ & $158(11)$ & $77(17)$ & \\
\hline & Tongue and oral cavity & $\mathrm{C} 01-06$ & $591(42)$ & $203(45)$ & \\
\hline & Salivary glands & C07-08 & $95(7)$ & $96(21)$ & \\
\hline & Pharynx & C09-13 & $529(38)$ & $70(16)$ & \\
\hline & Other ill-defined sites & $\mathrm{C} 14$ & $22(2)$ & $5(1)$ & \\
\hline \multirow[t]{5}{*}{ Stomach } & All & $\mathrm{C} 16$ & $2897(100)$ & $2412(100)$ & $p<0.001$ \\
\hline & Cardia & C16.0 & $249(9)$ & $136(6)$ & \\
\hline & Non-cardia & C16.1-16.4 & $1553(54)$ & $1308(54)$ & \\
\hline & Other & C16.5-16.8 & $238(8)$ & $223(9)$ & \\
\hline & Unspecified & C16.9 & $857(29)$ & $745(31)$ & \\
\hline \multirow[t]{6}{*}{ Colon } & All & C18 & $1974(100)$ & $2712(100)$ & $p<0.001$ \\
\hline & Right & C18.0-18.3 & $630(32)$ & $1055(39)$ & \\
\hline & Transverse & C18.4 & $181(9)$ & $308(11)$ & \\
\hline & Left & C18.5-18.7 & $1089(55)$ & $1263(47)$ & \\
\hline & Overlapping & C18.8 & $38(2)$ & $29(1)$ & \\
\hline & Unspecified & C18.9 & $36(2)$ & $57(2)$ & \\
\hline \multirow[t]{4}{*}{ Rectum } & All & C19-21 & $1603(100)$ & $1582(100)$ & $p<0.001$ \\
\hline & Rectosigmoid junction & C19 & $234(14)$ & $253(16)$ & \\
\hline & Rectum & $\mathrm{C} 20$ & $1326(83)$ & $1229(78)$ & \\
\hline & Anus, anal canal & $\mathrm{C} 21$ & $43(3)$ & $100(6)$ & \\
\hline \multirow[t]{6}{*}{ Skin melanoma } & All & $\mathrm{C} 44$ & $533(100)$ & $972(100)$ & $p<0.001$ \\
\hline & Head and neck & C44.0-44.4 & $74(14)$ & $133(14)$ & \\
\hline & Trunk & C44.5 & $280(52)$ & $280(29)$ & \\
\hline & Upper limbs & C44.6 & $54(10)$ & $147(15)$ & \\
\hline & Lower limbs & C44.7 & $78(15)$ & $352(36)$ & \\
\hline & Overlapping, unspecified & C44.8-44.9 & $47(9)$ & $60(6)$ & \\
\hline
\end{tabular}

${ }^{*}$ Chi-squared test.

subsite. Socioeconomic status has been shown to influence survival [18]. Co-morbidities, treatment compliance and health behaviour after diagnosis may also play a role, taking into consideration the major risk factors for these cancers, particularly smoking and alcohol consumption. Head and neck cancers associated with human papillomavirus (HPV) have better survival than HPV-negative tumours, which are mainly alcohol- or tobacco-related [19], but no data are available regarding the HPV prevalence in oropharyngeal tumours in Estonia.

For stomach cancer, we observed a 3-4\% unit female survival advantage, similar to that found in Germany and US [20]. Women had 10\% lower EHR of dying, which was not influenced by stage or subsite distribution. The analysis of EUROCARE-4 data demonstrated a similar female survival advantage [6]. In the Austrian study, women still had a survival advantage in an age- and stage-adjusted model [21], while in Korea, women's higher risk of death disappeared after adjusting for age and stage [22]. Several underlying mechanisms have been proposed for the protective effect of oestrogens against gastric cancer [23]. The presence of oestrogen receptors could protect against invasiveness of stomach cancer [24], but their prognostic role may be limited [25]. Body mass index (BMI) could be important in surgical outcomes, especially in men: male patients with high BMI were shown to have longer duration of operation and larger extent of bleeding compared to patients with lower BMI; no such difference was seen among female patients [26].

In contrast to some previous studies [5,6,27], we did not find female survival advantage for colon and rectum cancers. The reasons for this are not clear. There was a slight tendency towards female advantage during the 
Table 4 Stage distribution among cancer cases eligible for survival analysis, Estonia, 1995-2006

\begin{tabular}{|c|c|c|c|c|}
\hline \multirow[b]{2}{*}{ Cancer site } & \multirow[b]{2}{*}{ Extent } & \multicolumn{2}{|c|}{ No. of cases (\%) } & \multirow[b]{2}{*}{ p-value* } \\
\hline & & Men & Women & \\
\hline \multirow{5}{*}{$\begin{array}{l}\text { Mouth, } \\
\text { pharynx }\end{array}$} & All & $1395(100)$ & $451(100)$ & $p<0.001$ \\
\hline & Localized & $564(40)$ & $256(57)$ & \\
\hline & $\begin{array}{l}\text { Local/regional } \\
\text { spread }\end{array}$ & $752(54)$ & $169(37)$ & \\
\hline & Distant & $57(4)$ & $19(4)$ & \\
\hline & Unknown & $22(2)$ & $7(2)$ & \\
\hline \multirow[t]{5}{*}{ Stomach } & All & $2897(100)$ & $2412(100)$ & $p<0.001$ \\
\hline & Localized & $650(22)$ & $616(26)$ & \\
\hline & $\begin{array}{l}\text { Local/regional } \\
\text { spread }\end{array}$ & $739(26)$ & $579(24)$ & \\
\hline & Distant & 1404 (48) & $1090(45)$ & \\
\hline & Unknown & $104(4)$ & $127(5)$ & \\
\hline \multirow[t]{5}{*}{ Colon } & All & $1974(100)$ & $2712(100)$ & $p=0.048$ \\
\hline & Localized & $787(40)$ & $1039(38)$ & \\
\hline & $\begin{array}{l}\text { Local/regional } \\
\text { spread }\end{array}$ & $509(26)$ & $748(28)$ & \\
\hline & Distant & $625(32)$ & $819(30)$ & \\
\hline & Unknown & $53(3)$ & $106(4)$ & \\
\hline \multirow[t]{5}{*}{ Rectum } & All & $1603(100)$ & $1582(100)$ & $p=0.099$ \\
\hline & Localized & $681(42)$ & $637(40)$ & \\
\hline & $\begin{array}{l}\text { Local/regional } \\
\text { spread }\end{array}$ & $449(28)$ & $479(30)$ & \\
\hline & Distant & $432(27)$ & $407(26)$ & \\
\hline & Unknown & $41(3)$ & $59(4)$ & \\
\hline \multirow[t]{5}{*}{ Pancreas } & All & $1142(100)$ & $1035(100)$ & $p=0.114$ \\
\hline & Localized & $117(10)$ & $132(13)$ & \\
\hline & $\begin{array}{l}\text { Local/regional } \\
\text { spread }\end{array}$ & $271(24)$ & $245(24)$ & \\
\hline & Distant & $684(60)$ & $580(56)$ & \\
\hline & Unknown & $70(6)$ & $78(7)$ & \\
\hline \multirow[t]{5}{*}{ Lung } & All & $6948(100)$ & $1647(100)$ & $p=0.003$ \\
\hline & Localized & $1127(16)$ & $285(17)$ & \\
\hline & $\begin{array}{l}\text { Local/regional } \\
\text { spread }\end{array}$ & 2676 (39) & $567(34)$ & \\
\hline & Distant & $2846(41)$ & $699(42)$ & \\
\hline & Unknown & $299(4)$ & $96(6)$ & \\
\hline \multirow{5}{*}{$\begin{array}{l}\text { Skin } \\
\text { melanoma }\end{array}$} & All & $533(100)$ & $972(100)$ & $p<0.001$ \\
\hline & Localized & $360(68)$ & 761 (78) & \\
\hline & $\begin{array}{l}\text { Local/regional } \\
\text { spread }\end{array}$ & $98(18)$ & $108(11)$ & \\
\hline & Distant & $60(11)$ & $74(8)$ & \\
\hline & Unknown & $15(3)$ & $29(3)$ & \\
\hline
\end{tabular}

Table 4 Stage distribution among cancer cases eligible for survival analysis, Estonia, 1995-2006 (Continued)

\begin{tabular}{lllll}
\hline Kidney & All & $1617(100)$ & $1193(100)$ & $\mathrm{p}<0.001$ \\
& Localized & $876(54)$ & $728(61)$ & \\
Local/regional & $228(14)$ & $145(12)$ & \\
spread & & & \\
& Distant & $473(29)$ & $272(23)$ & \\
& Unknown & $40(3)$ & $48(4)$ & \\
All & $1760(100)$ & $659(100)$ & $\mathrm{p}=0.299$ \\
& Localized & $1325(75)$ & $486(74)$ & \\
& Local/regional & $213(12)$ & $87(13)$ & \\
& spread & & & \\
& Distant & $152(9)$ & $50(8)$ & \\
& Unknown & $70(4)$ & $36(5)$ & \\
\hline
\end{tabular}

${ }^{*}$ Chi-squared test.

most recent period, which warrants further analysis. The stage distributions did not differ between men and women in our study. For colon cancer, there was left predominance of colon cancer among men and righttransverse predominance among women; this pattern has been observed previously [27]. Several previous studies found that the women's advantage was agerelated. For example, in the EUROCARE analysis, the women's advantage was much larger in the age group 15-54 years [6] and in a SEER-based study, women had better survival than men until the age of 64 years [28]. In Germany, female advantage was most notable in younger-middle ages and the advantage varied by stage of CRC (larger for localised cancers) [27]. We did not find any age-related patterns in survival differences, possibly due to small numbers in younger age groups.

Women had 6\% units higher 5-year RSR for lung cancer in both periods, but the largest difference (13\% units) was seen amongst patients younger than 55 years of age. In the EUROCARE-4-based study, a significant difference between the age-specific relative survival of men and women was seen only among patients younger than 65 years [6]. After adjusting for age and stage, women in our study had nearly $20 \%$ lower EHR of dying than men. This estimate is very close to that found in an Austrian study after similar adjustment [21]. The proportion of small-cell lung cancer was $16 \%$ in both men and women; women had a higher proportion of adenocarcinomas and men had more squamous cell carcinomas, but the inclusion of this variable into the model had no considerable effect on the EHR of dying (data not shown). In a Dutch study, men with lung cancer had higher prevalence of co-morbid conditions than women; it was also shown that patients with co-morbidities (particularly the elderly) were treated less aggressively [29]. On the other hand, a SEER-based study of treated and untreated elderly patients suggested a different natural history and 
Table 5 Five-year relative survival ratios (RSR) in Estonia, women (W) and men (M), 1995-2006

\begin{tabular}{|c|c|c|c|c|c|c|c|c|c|c|c|c|c|c|c|c|c|c|}
\hline \multirow[b]{2}{*}{$\begin{array}{l}\text { Cancer } \\
\text { site }\end{array}$} & \multicolumn{3}{|c|}{$\begin{array}{l}\text { All ages } \\
\text { (age-adjusted) }\end{array}$} & \multicolumn{3}{|c|}{$15-44$} & \multicolumn{3}{|c|}{$45-54$} & \multicolumn{3}{|c|}{$55-64$} & \multicolumn{3}{|c|}{$65-74$} & \multicolumn{3}{|l|}{$\geq 75$} \\
\hline & $\begin{array}{l}\text { RSR } \\
(W) \\
\%\end{array}$ & $\begin{array}{l}\text { RSR } \\
\text { (M) } \\
\%\end{array}$ & $\begin{array}{l}\text { RSR(W) } \\
\text { minus } \\
\text { RSR(M) }\end{array}$ & $\begin{array}{l}\text { RSR } \\
\text { (W) } \\
\%\end{array}$ & $\begin{array}{l}\text { RSR } \\
(\mathrm{M}) \\
\%\end{array}$ & $\begin{array}{l}\text { RSR(W) } \\
\text { minus } \\
\text { RSR(M) }\end{array}$ & $\begin{array}{l}\text { RSR } \\
\text { (W) } \\
\%\end{array}$ & $\begin{array}{l}\text { RSR } \\
(\mathrm{M}) \\
\%\end{array}$ & $\begin{array}{l}\text { RSR(W) } \\
\text { minus } \\
\text { RSR(M) }\end{array}$ & $\begin{array}{l}\text { RSR } \\
(\mathrm{W}) \\
\%\end{array}$ & $\begin{array}{l}\text { RSR } \\
(\mathrm{M}) \\
\%\end{array}$ & $\begin{array}{l}\text { RSR(W) } \\
\text { minus } \\
\text { RSR(M) }\end{array}$ & $\begin{array}{l}\text { RSR } \\
(\mathrm{W}) \\
\%\end{array}$ & $\begin{array}{l}\text { RSR } \\
\text { (M) } \\
\%\end{array}$ & $\begin{array}{l}\text { RSR(W) } \\
\text { minus } \\
\text { RSR(M) }\end{array}$ & $\begin{array}{l}\text { RSR } \\
(\mathrm{W}) \\
\%\end{array}$ & $\begin{array}{l}\text { RSR } \\
\text { (M) } \\
\%\end{array}$ & $\begin{array}{l}\text { RSR(W) } \\
\text { minus } \\
\text { RSR(M) }\end{array}$ \\
\hline $\begin{array}{l}\text { Mouth, } \\
\text { pharynx }\end{array}$ & 52 & 30 & $22^{*}$ & 62 & 31 & $31^{*}$ & 55 & 26 & $29^{*}$ & 54 & 22 & $32^{*}$ & 48 & 37 & 11 & 51 & 30 & 21 \\
\hline Stomach & 23 & 20 & 3 & 26 & 31 & -5 & 29 & 22 & 7 & 28 & 24 & 4 & 23 & 18 & 5 & 16 & 16 & 0 \\
\hline Colon & 51 & 50 & 1 & 58 & 60 & -2 & 52 & 53 & -1 & 52 & 47 & 5 & 52 & 52 & 0 & 46 & 46 & 0 \\
\hline Rectum & 46 & 42 & 4 & 42 & 42 & 0 & 53 & 41 & 12 & 53 & 50 & 3 & 49 & 48 & 1 & 34 & 31 & 3 \\
\hline Pancreas & 6 & 5 & 1 & 15 & 17 & -2 & 12 & 5 & 7 & 5 & 6 & -1 & 5 & 2 & 3 & 3 & 5 & -2 \\
\hline Lung & 14 & 9 & $5^{*}$ & 28 & 15 & 13 & 23 & 10 & $13^{*}$ & 15 & 10 & 5 & 9 & 8 & 1 & 11 & 6 & 5 \\
\hline $\begin{array}{l}\text { Skin } \\
\text { melanoma }\end{array}$ & 73 & 56 & $17^{*}$ & 82 & 66 & $16^{*}$ & 75 & 60 & 15 & 69 & 51 & $18^{*}$ & 71 & 60 & 11 & 64 & 36 & 28 \\
\hline Kidney & 62 & 54 & $8^{*}$ & 82 & 64 & 18 & 77 & 56 & $21^{*}$ & 69 & 58 & $11^{*}$ & 56 & 56 & 0 & 51 & 45 & 6 \\
\hline Bladder & 65 & 63 & 2 & 78 & 88 & -10 & 72 & 80 & -8 & 73 & 66 & 7 & 67 & 60 & 7 & 50 & 50 & 0 \\
\hline
\end{tabular}

*Significant difference at the 0.05 level.

different tumour biology of lung cancer in men and women [30]. In addition, genetic and hormonal have been proposed as a potential explanation for the survival benefit experienced by women [31].

The absolute difference between the 5-year RSR of male and female melanoma patients increased from 14\% units to $19 \%$ units from 1995-2000 to 2001-2006 as survival did not improve in men. The 5-year RSR for women in Estonia in 2001-2006 was 12\% units lower than the European mean for 2000-2007 reported in EUROCARE-5 (75\% vs. $87 \%$ ), but the respective difference among men was as much as $23 \%$ units (56\% vs. $79 \%)$ [13]. We found female advantage in all age groups in our study, with a particularly large difference among patients age 75 years and over. The predominant subsite was trunk among men, but lower limbs among women.
Women were more likely to have localised melanoma. In age-adjusted analysis, female patients had almost 50\% lower EHR of death and this is consistent with the results of the analysis on the European pool [6]. Although men were more likely to have melanomas with unfavourable characteristics, such as location on the trunk and more advanced stage at diagnosis, these factors did not fully explain the women's survival advantage. In a large Dutch population-based study, men were nearly twice as likely to die from their melanoma compared with females after adjusting for a number of patient and tumour characteristics such as age, region, Breslow thickness, histology, body site as well as nodal and metastatic status [32]. In a Finnish study, male patients had worse survival than females in all site groups [33]. The persistent female survival advantage among cases with

Table 6 Age-adjusted five-year relative survival ratios (RSR) in Estonia, 1995-2006

\begin{tabular}{|c|c|c|c|c|c|c|}
\hline \multirow[b]{3}{*}{ Cancer site } & \multicolumn{2}{|l|}{ Men } & \multicolumn{2}{|l|}{ Women } & \multirow{3}{*}{$\begin{array}{l}\text { Difference, } \\
\text { 1995-2000* }\end{array}$} & \multirow{3}{*}{$\begin{array}{l}\text { Difference, } \\
\text { 2001-2006* }\end{array}$} \\
\hline & \multicolumn{2}{|c|}{ 5-year RSR (95\% CI) } & \multicolumn{2}{|c|}{ 5-year RSR (95\% CI) } & & \\
\hline & 1995-2000 & $2001-2006$ & $1995-2000$ & $2001-2006$ & & \\
\hline Mouth, pharynx & $28(22-34)$ & $32(26-37)$ & $48(40-56)$ & $56(48-63)$ & $20^{* *}$ & $24^{* *}$ \\
\hline Stomach & $20(18-23)$ & $20(18-23)$ & $23(20-25)$ & $24(21-27)$ & 3 & 4 \\
\hline Colon & $52(47-57)$ & $47(43-51)$ & $49(46-52)$ & $53(49-56)$ & -3 & 6 \\
\hline Rectum & $38(33-42)$ & $46(42-50)$ & $39(35-43)$ & $52(48-56)$ & 1 & 6 \\
\hline Pancreas & $5(3-8)$ & $4(3-7)$ & $7(4-10)$ & $4(3-7)$ & 2 & 0 \\
\hline Lung & $7(6-9)$ & $10(9-12)$ & $13(10-16)$ & $16(13-19)$ & $6^{* *}$ & $6^{* *}$ \\
\hline Skin melanoma & $58(50-66)$ & $56(49-62)$ & $72(66-76)$ & $75(70-79)$ & 14 & $19 * *$ \\
\hline Kidney & $54(48-60)$ & $54(49-59)$ & $58(52-62)$ & $67(62-71)$ & 4 & $13^{* *}$ \\
\hline Bladder & $62(57-67)$ & $63(59-67)$ & $64(57-70)$ & $66(59-72)$ & 2 & 3 \\
\hline
\end{tabular}

*Five-year RSR among women minus respective RSR among men.

**Significant difference at the 0.05 level. 
Table 7 Excess hazard ratio (EHR) of death within five years after diagnosis for women compared to men, Estonia, 1995-2006

\begin{tabular}{lllll}
\hline Cancer site & EHR $(\mathbf{9 5 \%} \mathbf{C l})^{*}$ & $\begin{array}{l}\text { EHR adjusted for age } \\
\mathbf{9 5 \%} \mathbf{C l})\end{array}$ & $\begin{array}{l}\text { EHR adjusted for age } \\
\text { and extent } \mathbf{9 5 \% ~ C l})\end{array}$ & $\begin{array}{l}\text { EHR adjusted for age, extent } \\
\text { and subsite }\end{array}$ \\
\hline Mouth, pharynx & $0.54(0.46-0.63)$ & $0.54(0.46-0.64)$ & $0.60(0.51-0.71)$ & $0.66(0.56-0.78)$ \\
Stomach & $0.92(0.86-0.98)$ & $0.88(0.82-0.94)$ & $0.90(0.84-0.96)$ & $0.91(0.85-0.97)$ \\
Colon & $1.05(0.96-1.15)$ & $1.01(0.92-1.11)$ & $1.10(1.00-1.21)$ & $1.09(0.99-1.19)$ \\
Rectum & $0.98(0.88-1.10)$ & $0.92(0.83-1.03)$ & $1.00(0.90-1.11)$ & $0.99(0.89-1.10)$ \\
Pancreas & $1.00(0.91-1.09)$ & $0.94(0.85-1.03)$ & $0.97(0.88-1.06)$ & $0.72(0.58-0.90)$ \\
Lung & $0.90(0.85-0.96)$ & $0.87(0.82-0.93)$ & $0.81(0.76-0.86)$ & \\
Skin melanoma & $0.53(0.43-0.66)$ & $0.52(0.43-0.64)$ & $0.68(0.55-0.84)$ & $0.81(0.70-0.93)$ \\
Kidney & $0.76(0.67-0.87)$ & $0.72(0.63-0.83)$ & $0.96(0.80-1.15)$ & \\
Bladder & $1.03(0.86-1.24)$ & $0.92(0.77-1.11)$ &
\end{tabular}

*All models include year of follow-up and period of diagnosis.

**Mouth, pharynx: lip (ICD-O-3 C00), oral cavity and tongue (C01-06), salivary glands (C07-08), pharynx and other (C09-14); Stomach: cardia (C16.0), non-cardia (C16.1-16.4), other (C16.5-16.9); Colon: right (C18.0-18.3), transverse (C18.4), left (C18.5-18.7), other (C18.8-18.9); Rectum: rectosigmoid junction (C19), rectum (C20), anus and anal canal (C21); Skin melanoma: head and neck (C44.0-44.4), trunk (C44.5), upper limbs (C44.6), lower limbs (C44.7), other (C44.8-44.9).

pathology confirmed advanced disease suggested different immunological response to melanoma [32]. At the same time, the unfavourable effect of lower socioeconomic status on melanoma survival was also more pronounced among men than among women [34].

Female kidney cancer patients had around 20\% lower EHR of dying than males in our study. This difference is larger than seen in the EUROCARE-4 analysis [6]. The 5-year RSR for women in Estonia in 2001-2006 was 5\% units higher than the respective European mean in EUROCARE- 5 analysis (67\% vs. 62\%), but for men the difference was $6 \%$ in favour of the European mean (54\% vs. $60 \%$ ) [13]. Some previous studies have shown worse survival for women [22] or no difference [21] while many studies have reported women's survival advantage [35]. Kidney cancer survival improved over the study period only among women in Estonia. Women showed more favourable stage distribution which may be related to the increasing use of modern abdominal imaging techniques. Greater use of diagnostic imaging may result in the diagnosis of more incidental renal cell carcinomas among females than males and these tumours have better prognosis compared with symptomatic tumours [35]. The comparison of age-specific RSRs revealed that women's significant survival advantage was limited to patients under the age of 65 years.

Previous population-based studies have found poorer outcomes for bladder cancer in women compared to men $[5,6,21,22]$. We found non-significantly higher RSRs for men among patients younger than 55 years, but overall analysis did not reveal any differences. The male advantage has been associated with different management and referral practices [36,37]. In Estonia, women visit doctors much more often than men; the proportion of men who had visited a specialist physician during the past year has been consistently about 18\% units lower than that of women (33\% vs. $51 \%$ in 2002 and $41 \%$ vs. $59 \%$ in 2012) [16].

\section{Conclusions}

The age-adjusted 5-year RSR was higher among women than men for all nine cancer sites included in the study. A statistically significant female advantage in the 5-year RSR was seen for cancers of mouth and pharynx, lung, kidney and skin melanoma. The differences in favour of women tended to increase over time, as survival improved more among women than among men over the study period. For several sites, the survival gap between the most recent estimates for Estonia and the rest of Europe was much larger for men than for women.

Age was a significant contributor to gender survival differences, but its role was not uniform across the cancer sites studied. For lung and kidney cancer, the women's advantage was largest before age 55 years, suggesting the role of hormonal factors; for mouth and pharyngeal cancer and melanoma, the advantage was very large until age 65 and increased again in patients age 75 years and older, suggesting the combined effect of biological and social factors as well as co-morbidities. For five sites (mouth and pharynx, stomach, lung, skin melanoma and kidney), women had a significantly lower EHR of dying in multivariate analysis that was not explained by age, stage or subsite.

A large part of the women's advantage is likely attributable to biological factors, including hormonal status or different molecular subtypes. The magnitude of the women's advantage observed in this study suggests that the other factors, such as co-morbidities, treatment compliance and/or health behaviour (including degree of change in health behaviour after diagnosis) could be contributors to gender disparities in Estonia and merit further investigation using high-resolution approach. 
As some of these factors are modifiable, our findings have implications for public health, early detection and cancer care strategies in Estonia.

\section{Competing interests}

The authors declare that they have no competing interests.

\section{Authors' contributions}

$\mathrm{KI}$ participated in the design of the study, performed the statistical analysis and drafted the manuscript. TA participated in the design of the study and drafted the manuscript. PP and W participated in the interpretation of the results and critically revised the manuscript. All authors read and approved the final manuscript.

\section{Acknowledgements}

The work of KI and TA was supported by Estonian Research Council (grant no IUT5-1) and European Regional Development Fund (Estonian Research Council, program TerVE, project EVRKA, contract no. 2-14.3.1/13/8). The authors thank Dr Margit Mägi and Mrs Pille Härmaorg from the Estonian Cancer Registry for providing the data, and Aleksei Baburin for technical help.

\section{Author details}

'Department of Epidemiology and Biostatistics, National Institute for Health Development, Hiiu 42, 11619 Tallinn, Estonia. ${ }^{2}$ Clinic of Haematology and Oncology, Tartu University Hospital, Tartu, Estonia. ${ }^{3} \mathrm{Cl}$ linic of Haematology and Oncology, University of Tartu, Tartu, Estonia. ${ }^{4}$ Clinic of Oncology and Haematology, North Estonia Medical Centre, Tallinn, Estonia. ${ }^{5}$ Competence Centre for Cancer Research, Tallinn, Estonia.

\section{Received: 29 October 2014 Accepted: 10 February 2015 \\ Published online: 19 February 2015}

\section{References}

1. European Commission. Life expectancy at birth by sex. [http://epp.eurostat ec.europa.eu/tgm/refreshTableAction.do?tab=table\&plugin=1\&pcode= tps00025\&language $=e n]$

2. Statistics Estonia. Statistical Database. [http://pub.stat.ee/px-web.2001/ I_Databas/Population/databasetree.asp]

3. European Commission. Causes of death statistics. [http://ec.europa.eu/eurostat/ statistics-explained/index.php/Causes_of_death_statistics]

4. Ferlay J, Soerjomataram I, Ervik M, Dikshit R, Eser S, Mathers C et al. GLOBOCAN 2012 v1.0, Cancer Incidence and Mortality Worldwide: IARC CancerBase No. 11. [http://globocan.iarc.fr]

5. Cook MB, McGlynn KA, Devesa SS, Freedman ND, Anderson WF. Sex disparities in cancer mortality and survival. Cancer Epidemiol Biomarkers Prev. 2011;20:1629-37.

6. Micheli A, Ciampichini R, Oberaigner W, Ciccolallo L, de Vries E, Izarzugaza I, et al. The advantage of women in cancer survival: an analysis of EUROCARE4 data. Eur J Cancer. 2009;45:1017-27.

7. Micheli A, Mariotto A, Giorgi RA, Gatta G, Muti P, EUROCARE Working Group. The prognostic role of gender in survival of adult cancer patients. Eur J Cancer. 1998:34:2271-8.

8. Coleman MP, Gatta G, Verdecchia A, Esteve J, Sant M, Storm H, et al. EUROCARE-3 summary: cancer survival in Europe at the end of the 20th century. Ann Oncol. 2003;14 Suppl 5:v128-49.

9. Rahu M. Estonia. In: Parkin DM, Muir CS, Whelan SL, Gao Y-T, Ferlay J, Powell J, editors. Cancer Incidence in Five Continents, Vol VII. Lyon: International Agency for Research on Cancer; 1997. p. 569-73.

10. Innos K, Rahu M, Rahu K. Feasibility of cohort studies in Estonia. Occup Environ Med. 1999;56:499-502.

11. Corazziari I, Quinn M, Capocaccia R. Standard cancer patient population for age standardising survival ratios. Eur J Cancer. 2004;40:2307-16.

12. Dickman PW, Coviello E, Hills M: Estimating and modelling relative survival. [http://www.pauldickman.com/survival/strs.pdf]

13. De Angelis R, Sant M, Coleman MP, Francisci S, Baili P, Pierannunzio D, et al. Cancer survival in Europe 1999-2007 by country and age: results of EUROCARE-5-a population-based study. Lancet Oncol. 2014;15:23-34.

14. Shahabi S, He S, Kopf M, Mariani M, Petrini J, Scambia G, et al. Free testosterone drives cancer aggressiveness: evidence from US population studies. PLoS One. 2013;8:e61955.
15. Innos K, Baburin A, Aareleid T. Cancer patient survival in Estonia 1995-2009: time trends and data quality. Cancer Epidemiol. 2014;38:253-8.

16. Tekkel M, Veideman T. Eesti täiskasvanud rahvastiku tervisekäitumise uuring, 2012. Health Behavior Among Estonian Adult Population, 2012. Tallinn: National Institute for Health Development; 2013.

17. Zigon G, Berrino F, Gatta G, Sanchez MJ, van Dijk B, Van Eycken E, et al. Prognoses for head and neck cancers in Europe diagnosed in 1995-1999: a population-based study. Ann Oncol. 2011;22:165-74.

18. Andersen ZJ, Lassen CF, Clemmensen IH. Social inequality and incidence of and survival from cancers of the mouth, pharynx and larynx in a population-based study in Denmark, 1994-2003. Eur J Cancer. 2008:44:1950-61.

19. Chaturvedi AK, Engels EA, Pfeiffer RM, Hernandez BY, Xiao W, Kim E, et al. Human papillomavirus and rising oropharyngeal cancer incidence in the United States. J Clin Oncol. 2011:29:4294-301.

20. Hiripi E, Jansen L, Gondos A, Emrich K, Holleczek B, Katalinic A, et al. Survival of stomach and esophagus cancer patients in Germany in the early 21st century. Acta Oncol. 2012;51:906-14.

21. Oberaigner W, Siebert U. Do women with cancer have better survival as compared to men after adjusting for staging distribution? Eur J Public Health. 2011;21:387-91.

22. Jung KW, Park S, Shin A, Oh CM, Kong HJ, Jun JK, et al. Do female cancer patients display better survival rates compared with males? Analysis of the Korean National Registry data, 2005-2009. PLoS One. 2012;7:e52457.

23. Camargo MC, Goto Y, Zabaleta J, Morgan DR, Correa P, Rabkin CS. Sex hormones, hormonal interventions, and gastric cancer risk: a meta-analysis. Cancer Epidemiol Biomarkers Prev. 2012;21:20-38.

24. Ryu WS, Kim JH, Jang YJ, Park SS, Um JW, Park SH, et al. Expression of estrogen receptors in gastric cancer and their clinical significance. J Surg Oncol. 2012;106:456-61.

25. Gan L, He J, Zhang X, Zhang YJ, Yu GZ, Chen Y, et al. Expression profile and prognostic role of sex hormone receptors in gastric cancer. BMC Cancer. 2012;12:566.

26. Lee SS, Ryu SW, Kim IH, Sohn SS. Impact of gender and body mass index on surgical outcomes following gastrectomy: an Asia-Pacific perspective. Chin Med J. 2012;125:67-71.

27. Majek O, Gondos A, Jansen L, Emrich K, Holleczek B, Katalinic A, et al. Sex differences in colorectal cancer survival: population-based analysis of 164,996 colorectal cancer patients in Germany. PLoS One. 2013;8:e68077.

28. Purim O, Gordon N, Brenner B. Cancer of the colon and rectum: potential effects of sex-age interactions on incidence and outcome. Med Sci Monit. 2013;19:203-9.

29. Janssen-Heijnen ML, Houterman S, Lemmens VE, Louwman MW, Maas HA, Coebergh JW. Prognostic impact of increasing age and co-morbidity in cancer patients: a population-based approach. Crit Rev Oncol Hematol. 2005;55:231-40.

30. Wisnivesky JP, Halm EA. Sex differences in lung cancer survival: do tumors behave differently in elderly women? J Clin Oncol. 2007;25:1705-12.

31. Planchard D, Loriot Y, Goubar A, Commo F, Soria JC. Differential expression of biomarkers in men and women. Semin Oncol. 2009;36:553-65.

32. de Vries E, Nijsten TE, Visser O, Bastiaannet E, van Hattern S, Janssen-Heijnen ML, et al. Superior survival of females among 10,538 Dutch melanoma patients is independent of Breslow thickness, histologic type and tumor site. Ann Oncol. 2008;19:583-9.

33. Karjalainen $\mathrm{S}$, Hakulinen $\mathrm{T}$. Survival and prognostic factors of patients with skin melanoma. A regression-model analysis based on nationwide cancer registry data. Cancer. 1988:62:2274-80.

34. Birch-Johansen F, Hvilsom G, Kjaer T, Storm H. Social inequality and incidence of and survival from malignant melanoma in a population-based study in Denmark, 1994-2003. Eur J Cancer. 2008;44:2043-9.

35. Beisland C, Medby PC, Beisland HO. Renal cell carcinoma: gender difference in incidental detection and cancer-specific survival. Scand J Urol Nephrol. 2002;36:414-8.

36. Garg T, Pinheiro LC, Atoria CL, Donat SM, Weissman JS, Herr HW, et al. Gender Disparities in hematuria evaluation and bladder cancer diagnosis: a population based analysis. J Urol. 2014;192:1072-7.

37. Henning A, Wehrberger M, Madersbacher S, Pycha A, Martini T, Comploj E, et al. Do differences in clinical symptoms and referral patterns contribute to the gender gap in bladder cancer? BJU Int. 2013;112:68-73. 